УДК 352/354-043.5(477)

DOI https://doi.org/10.32837/pyuv.v0i1(30).519

\author{
Я.В. Журавель \\ orcid.org/0000-0001-8508-5530 \\ кандидат юридичних наук, доцент, \\ декан юридичного факультету \\ Академії праці, соціальних відносин і туризму
}

\title{
НОРМАТИВНО-ПРАВОВИЙ РІВЕНЬ ОПТИМІЗАЦІЇ СИСТЕМИ ЦЕНТРАЛЬНИХ ОРГАНІВ ВИКОНАВЧОЇ ВЛАДИ В УКРАЇНІ
}

Постановка проблеми. Нормативно-правовий рівень оптимізації центральних органів виконавчої влади є важливим структурним компонентом організації ефективного державного управління. Від структурно-системних складників нормативно-правового регулювання залежить не лише статус, порядок організації і функціональні характеристики органів виконавчої влади, а й питання контролю виконання покладених на них завдань, а також рівень юридичної техніки забезпечення адміністративної діяльності та зручність користування необхідною нормативно-правовою документацією.

Однією з пріоритетних сфер адміністративної реформи в Україні є створення нової правової бази, що регламентуватиме державне управління в Україні [1, с. 7]. На нагальні потреби оптимізації органів виконавчої влади вказує і С.В. Пєтков, зазначивши, що оптимізація неефективних структур - це потреба часу [2, с. 98].

Стан наукового дослідження. Нормативно-правове регулювання оптимізації органів виконавчої влади було предметом дослідження В.Б. Авер'янова, Я.Б. Глущенкота, І.Б. Коліушка, С.В. Пєткова, B.I. Теремецького та інших вчених. В.I. Теремецький в одній зі своїх праць проаналізував правові, організаційні, кадрові та інші аспекти процесу операційної і функціональної інтеграції Податкової та Митної служб в єдиний фіскальний орган - Міністерство доходів і зборів України [3]. Однак існуюча нелогічність правового регулювання та колізійність правових норм на нормативно-правовому рівні оптимізації центральних органів виконавчої влади спонукають до нових наукових досліджень у цьому напрямі.

Метою статті $є$ визначення шляхів вирішення проблем нормативно-правового регулювання організації та діяльності центральних органів виконавчої влади, а також надання пропозицій щодо правової конструкції нормативно-правового рівня оптимізації системи центральних органів виконавчої влади.

Виклад основного матеріалу. Питання організації діяльності органів державної виконавчої влади регламентовано Конституцією України [4], Законами України «Про Кабінет Міністрів України» [5], «Про центральні органи виконавчої вла- ди» [6], постановою Кабінету Міністрів України «Деякі питання оптимізації системи центральних органів виконавчої влади» [7] та низкою інших нормативно-правових актів.

Нормативно-правовий рівень оптимізації системи органів виконавчої влади є системою нормативно-правових актів, які регламентують структуру та функціональні характеристики системи органів виконавчої влади, їх правовий статус, повноваження та відповідальність. Нормативно-правовий рівень характеризується такими принципами:

- верховенства права - всі нормативно-правові акти, що регулюють організацію та діяльність органів виконавчої влади, мають відповідати Конституції України, а Конституція має відповідати загальновизнаним світовим співтовариством принципам справедливості;

- стабільності законодавства - Конституція України та закони України, зокрема i ті, що регулюють питання діяльності органів виконавчої влади, повинні бути стабільними і змінюватися лише за необхідності, що є однією з ознак правової та високоорганізованої держави;

- мобільності законодавства - підзаконні нормативно-правові акти, що регулюють питання організації та функціонування органів виконавчої влади, мають змінюватися, оскільки в демократичних державах відбуваються перманентні реформи, органи виконавчої влади постійно реформуються, виділяються, розділяються або ж ліквідовуються, змінюються їхні функції.

Оскільки діяльність центральних органів виконавчої влади регулюється значною кількістю нормативно-правових актів різної юридичної сили, то у структурі нормативно-правового рівня оптимізації центральних органів виконавчої влади доцільно виділити концептуальний і функціональний субрівні.

В межах концептуального субрівня здійснюється правова регламентація статусу, структури, порядку утворення, ліквідації, реорганізації центральних органів виконавчої влади, порядку призначення керівництва, повноваження керівника, а також завдання, функціїіповноваження центрального органу виконавчої влади. Концептуальний 
субрівень нормативно-правового рівня оптимізації органів виконавчої влади має основний, установчий характер, є нормативно-правовим базисом діяльності центральних органів виконавчої влади.

Що ж стосується функціонального субрівня, то він має допоміжний, доповнюючий характер щодо концептуального субрівня, в межах якого здійснюється нормативно-правове регулювання повноважень і функцій центральних органів виконавчої влади в певних сферах суспільно-державної життєдіяльності.

На думку автора, в межах концептуального субрівня правове регулювання структури та функціоналу центральних органів державної виконавчої влади має чотири ступені нормативно-правового регулювання. Перший ступінь - закріплення в Конституції України [4] статусу Кабінету Міністрів України як вищого органу в системі органів виконавчої влади України. Зокрема, у Конституції України визначено відповідальність, підконтрольність і підзвітність Кабінету Міністрів України; склад і порядок призначення членів Кабінету Міністрів України; порядок вступу у повноваження і порядок припинення повноважень Кабінету Міністрів України; повноваження Кабінету Міністрів України.

Другий ступінь нормативно-правового регулювання системи центральних органів виконавчої влади концептуального субрівня - деталізація статусу Кабінету Міністрів України на рівні органічного закону (як приклад можна навести Закон України «Про Кабінет Міністрів України»). Порівняно з Конституцією України, Закон України «Про Кабінет Міністрів України» має такі деталізації: визначено основні завдання та принципи діяльності Кабінету Міністрів України; встановлено вимоги до членів і програми діяльності Кабінету Міністрів України; регламентовано особливості продовження виконання повноважень Кабінетом Міністрів України та окремими його членами у визначених випадках; урегульовано особливості повноважень Кабінету Міністрів України у відносинах з органами публічної влади, в тому числі з органами виконавчої влади, Президентом України, Верховною Радою України, іншими державними органами, органами місцевого самоврядування; унормовано організацію діяльності Кабінету Міністрів України, а також соціальне та інше забезпечення членів Кабінету Міністрів України.

Третій ступінь - це визначення загальних основ їх статусу в Законі України «Про центральні органи виконавчої влади" [6], яким визначено систему центральних органів виконавчої влади, принципи та правові засади їх діяльності, а також порядок утворення, ліквідації та реорганізації; окремими розділами визначено статус, завдання, повноваження керівників, статус апарату, територіальних органів, консультативних, дорадчих та інших допоміжних органів, нормативно-правових актів міністерств та інших центральних органів виконавчої влади; регламентовано питання забезпечення діяльності та відповідальності посадових осіб центральних органів виконавчої влади.

Четвертий ступінь - детальне регулювання статусу конкретних міністерств та інших центральних органів виконавчої влади, що здійснюється на основі положень про органи, затверджені Кабінетом Міністрів України. Зокрема, у положеннях про центральні органи виконавчої влади передбачено статус центрального органу виконавчої влади; сфери, в яких центральний орган виконавчої влади реалізує державну політику; завдання та повноваження центрального органу виконавчої влади; повноваження керівника центрального органу виконавчої влади; структуру керівництва центрального органу виконавчої влади та порядок призначення заступників керівника; порядок взаємодії з іншими органами влади та місцевого самоврядування, допоміжними та дорадчими органами, організаціями громадянського суспільства; повноваження державного секретаря як вищої посадової особи з числа державних службовців (актуально лише для міністерств).

Як приклад положень про центральні органи виконавчої влади можна навести Положення про Міністерство охорони здоров'я України, затверджене постановою Кабінету Міністрів України від 25.03.2015 № 267 (у редакції постанови Кабінету Міністрів України від 24.01.2020 № 90) [8], Положення про Державну службу України з лікарських засобів та контролю за наркотиками, затверджене постановою Кабінету Міністрів України від 12.08.2015 № 647 [9], Положення про Національне агентство України з питань виявлення, розшуку та управління активами, одержаними від корупційних та інших злочинів, затверджене постановою Кабінету Міністрів України від 11.07.2018 № 613 [10] та інші положення про центральні органи виконавчої влади.

Щодо структури функціонального субрівня нормативно-правового рівня оптимізації центральних органів виконавчої влади автор вважає, що вона включає два ступені нормативно-правового регулювання - ступінь регулювання законами та ступінь регулювання підзаконними нормативно-правовими актами. Досить часто діяльність органів центральної виконавчої влади регулюється саме законами. Так, певні функції та завдання Мiністерства охорони здоров'я України визначено Законом України «Основи законодавства України про охорону здоров'я», функції та завдання Національної служби здоров'я України - Законом України «Про державні фінансові гарантії медичного обслуговування населення», функції та завдання Міністерства освіти і науки України - Законами України «Про освіту», «Про вищу освіту» тощо. 
Регулюють питання діяльності центральних органів виконавчої влади і підзаконні акти. Зокрема, деякі функції та повноваження Національної служби здоров'я України передбачено постановами Кабінету Міністрів України «Про договори про медичне обслуговування населення за програмою медичних гарантій” від 25.04.2018 № 410 [11], «Деякі питання електронної системи охорони здоров’я» від 25.04.2018 № 411 [12]. Постановою Кабінету Міністрів України «Про державну реєстрацію авторського права і договорів, які стосуються права автора на твір» від 27.12.2001 № 1756 [13] визначено деякі функції Міністерства розвитку економіки, торгівлі та сільського господарства України.

Стосовно концептуального субрівня нормативно-правового рівня оптимізації центральних органів виконавчої влади слід зауважити, що нормативно-правове регулювання деяких центральних органів виконавчої влади не відповідає запропонованій автором конструкції нормативно-правового рівня. Така ситуація виникла тому, що статус та функціонування певних центральних органів виконавчої влади концептуально врегульовано не положеннями, що затверджуються Кабінетом Мiністрів України, а саме законами України.

Зокрема, статус і функціонування Державного бюро розслідувань визначається Законом України «Про Державне бюро розслідувань», статус і функціонування Антимонопольного комітету України - Законом України «Про Антимонопольний комітет України», статус і функціонування Фонду державного майна України - Законом України «Про Фонд державного майна України», статус і функціонування Національного агентства з питань запобігання корупції - Законом України «Про запобігання корупції, статус і функціонування Національного агентства України з питань виявлення, розшуку та управління активами, одержаними від корупційних та інших злочинів, визначається як Положенням про Національне агентство України $з$ питань виявлення, розшуку та управління активами, одержаними від корупційних та інших злочинів, затвердженим постановою Кабінету Мiністрів України від 11.07.2018 № 613, так і Законом України «Про Національне агентство України 3 питань виявлення, розшуку та управління активами, одержаними від корупційних та інших злочинів», статус і функціонування Національної поліції України визначається як Положенням про Національну поліцію, затвердженим постановою Кабінету Міністрів України від 28.10.2015 № 877, так і Законом України «Про Національну поліцію». Всі інші центральні органи виконавчої влади здійснюють свою діяльність на основі положень, затверджених постановами Кабінету Міністрів України, які визначають їх статус і функціонал.

Однак наведені вище факти свідчать про неоднаковий підхід до нормативно-правового регулю- вання статусу та функціонування центральних органів виконавчої влади. Таку ситуацію можна визначити як асиметрію нормативно-правового рівня оптимізації центральних органів виконавчої влади на концептуальному субрівні. Так, в Україні не існує Закону України «Про Міністерство внутрішніх справ України» чи Закону України «Про Міністерство освіти і науки України», а Закони України «Про Національну поліцію», «Про Державне бюро розслідувань», «Про Національне агентство України з питань виявлення, розшуку та управління активами, одержаними від корупційних та інших злочинів» не лише існують, але й регулюють організацію та діяльність відповідних центральних органів виконавчої влади.

Такий асиметричний підхід до нормативно-правового регулювання статусу та функціонування центральних органів виконавчої влади ставить на один рівень із Кабінетом Міністрів України, організація та діяльність якого на концептуальному субрівні регламентується Конституцією України та Законом України «Про Кабінет Міністрів України», такі органи як Державне бюро розслідувань, Антимонопольний комітет України, Фонд державного майна України, Національне агентство з питань запобігання корупції, Національне агентство України з питань виявлення, розшуку та управління активами, одержаними від корупційних та інших злочинів, Національну поліцію України.

Водночас Кабінет Міністрів України є вищим органом в системі органів виконавчої влади, а тому всі інші центральні органи виконавчої влади підконтрольні і підзвітні йому. До того ж регулювання статусу та діяльності вказаних центральних органів виконавчої влади на концептуальному рівні одночасно законами України та положеннями, затвердженими постановами Кабінету Міністрів України, є недоцільним, оскільки дублювання регламентації одних і тих же правовідносин двома або більше нормативно-правовими актами є небажаним.

Крім того, такі правоохоронні державні органи як Національне антикорупційне бюро України та Служба безпеки України, структура та функціонал яких на концептуальному субрівні визначаються Законами України «Про Національне антикорупційне бюро України» [14] та «Про Службу безпеки України" [15], за чинним національним законодавством не вважаються центральними органами виконавчої влади, хоча за своєю сутністю є саме такими. Адже Національне антикорупційне бюро України і Служба безпеки України мають багато схожого (як правоохоронні органи) з Національною поліцію України та Державним бюро розслідувань, які є центральними органами виконавчої влади. Їхня відмінність полягає лише у підслідності, тобто сферах діяльності, а також в зумовленій цим різниці статусів. 
Можливо, з наведеною думкою про асиметрію нормативно-правового рівня оптимізації центральних органів виконавчої влади не погодяться деякі дослідники через її невідповідність конституційній нормі. Так, згідно зі ст. 92 Конституції України виключно законами України, зокрема, визначаються організація і діяльність органів досудового розслідування [4]. Однак, Конституцію України за потреби теж можна змінити, далеко не всі зазначені вище асиметрично урегульовані центральні органи виконавчої влади є органами досудового розслідування.

Що стосується функціонального субрівня нормативно-правового рівня оптимізації центральних органів виконавчої влади, то є нагальна потреба уникнення нормативної авторегуляції ситуації, за якої центральний орган виконавчої влади сам видає нормативно-правовий акт, який сам же має виконувати і контролювати. Автор вважає, що така постановка питання є нелогічною та має прямі ознаки конфлікту інтересів. Наприклад, відповідно до ч. 3 ст. 48 Закону України «Про запобігання корупції» порядок проведення контролю декларацій затверджується Національним агентством $з$ питань запобігання корупції, яке і здійснює цей контроль [16].

Висновки. Так, нормативно-правовий рівень оптимізації центральних органів виконавчої влади має два субрівні: концептуальний і функціональний. Концептуальний субрівень має основний, установчий характер, є нормативно-правовим базисом діяльності центральних органів виконавчої влади. Функціональний субрівень має допоміжний, доповнюючий характер, в межах якого здійснюється нормативно-правове регулювання повноважень і функцій центральних органів виконавчої влади в певних сферах суспільно-державної життедіяльності. У зв'язку з асиметрією нормативно-правового рівня оптимізації центральних органів виконавчої влади на концептуальному субрівні необхідно змінювати структуру законодавства. Тому організація і діяльність центральних органів виконавчої влади має регулюватися положеннями, затвердженими Кабінетом Міністрів України, а не законами.

Важливим напрямом діджиталізації нормативно-правового рівня оптимізації системи центральних органів виконавчої влади є створення та широке впровадження у правотворчу практику комп'ютерних програм, які б перевіряли проєкти нормативно-правових актів, що регламентують діяльність органів виконавчої влади, на відповідність Конституції України та іншим нормативно-правовим актам вищої юридичної сили, відсутність або наявність неузгодженостей і дублювань 3 іншими документами, що регулюють схожі групи правовідносин. Така новація дозволила б суттєво підвищити рівень юридичної техні- ки при створенні нових і внесенні змін до чинних нормативно-правових актів, які регламентують діяльність центральних органів виконавчої влади.

Недосконалість нормативно-правового регулювання організації та діяльності органів виконавчої влади стримує проведення функціональної та структурної реформ системи виконавчої влади, а тому потребує комплексного аналізу та невідкладного вирішення, що і стане метою подальших досліджень автора.

\section{Jimepamypa}

1. Глущенко Я.Б. Адміністративно-правові засади реформування органів виконавчої влади : автореф. дис. канд. юрид. наук: 12.00 .07 . К., 2011. 18 с.

2. Пєтков С.В., Мехтієва Т.В. Антикризова модель відносин між громадянами та державою. Вісник Чернівецького факультету Національного університету «Одеська юридична академія». 2016. № 1. С. 87-99.

3. Теремецький B.I. Окремі аспекти об'єднання податкової та митної служб. Форум права. 2013. № 1. C. 1012-1017. URL: http://nbuv.gov.ua/UJRN/FP index.htm_2013_1_167.

4. Конституція України : Закон України від 28.06.1996 № 254к/96-BP. URL: https://zakon.rada. gov.ua/laws/show/254\% D0 \% BA/96- $\%$ D0 \% B2 \% D $1 \% 80$.

5. Про Кабінет Міністрів України : Закон України від 27.02.2014 № 794-VII. URL: https://zakon.rada. gov.ua/laws/show/794-18.

6. Про центральні органи виконавчої влади : Закон України від 17.03.2011 № 3166-VI. URL: https://zakon.rada.gov.ua/laws/show/3166-17.

7. Деякі питання оптимізації системи центральних органів виконавчої влади : постанова Кабінету Міністрів України від 11.03.2020 № 212. URL: https://zakon.rada.gov.ua/laws/show/212-2020-\% D0 $\%$ BF.

8. Положення про Міністерство охорони здоров'я України : постанова Кабінету Міністрів України від 25.03.2015 № 267 (у редакції від 24.01.2020 № 90). URL: https://zakon.rada.gov.ua/laws/show/ $267-2015-\% \mathrm{D} 0 \% \mathrm{BF}$.

9. Положення про Державну службу України з лікарських засобів та контролю за наркотиками : постанова Кабінету Міністрів України від 12.08.2015 № 647. URL: https://zakon.rada.gov.ua/laws/show/ 647-2015-\% D0\% BF.

10. Положення про Національне агентство України 3 питань виявлення, розшуку та управління активами, одержаними від корупційних та інших злочинів : постанова Кабінету Міністрів України від 11.07.2018 № 613. URL: https://zakon.rada.gov.ua/laws/show/ $613-2018-\%$ D0 \% BF.

11. Про договори про медичне обслуговування населення за програмою медичних гарантій : постанова Кабінету Міністрів України від 25.04.2018 № 410. URL: https://zakon.rada.gov.ua/laws/show/410-2018-\% $\mathrm{D} 0 \% \mathrm{BF}$.

12. Деякі питання електронної системи охорони здоров'я : постанова Кабінету Міністрів України від 25.04.2018 № 411. URL: https://zakon.rada.gov.ua/ laws/show/411-2018- $\%$ D0 \% BF.

13. Про державну реєстрацію авторського права і договорів, які стосуються права автора на твір : постанова Кабінету Міністрів України від 27.12.2001 № 1756. URL: https://zakon.rada.gov.ua/laws/show/1756-2001$\% \mathrm{D} 0 \% \mathrm{BF}$. 
14. Про Національне антикорупційне бюро України : Закон України від 14.10.2014 № 1698-VII. URL: https://zakon.rada.gov.ua/laws/show/1698-18.

15. Про Службу безпеки України : Закон України від 25.03.1992 № 2229-XII. URL: https://zakon.rada.gov.ua/laws/show/2229-12.

16. Про запобігання корупції : Закон України від 14.10.2014 № 1700-VII. URL: http://zakon.rada.gov.ua/ laws/show/1700-18.

\section{Анотація}

Журавель Я. В. Нормативно-правовий рівень оптимізації системи центральних органів виконавчої влади в Україні. - Стаття.

У статті з'ясовано, що від структурно-системних складників нормативно-правового регулювання залежить не лише статус, порядок організації і функціональні характеристики органів виконавчої влади, а й питання контролю щодо виконання покладених на них завдань, а також рівень юридичної техніки забезпечення адміністративноїдіяльності та зручність користування необхідною нормативно-правовою документацією.

Визначено, що нормативно-правовий рівень має характеризуватися такими ознаками: принципом верховенства права, принципом стабільності законодавства, принципом мобільності законодавства. Теоретично обгрунтовано, що однією з пріоритетних сфер адміністративної реформи в Україні є створення нової правової бази, яка регламентуватиме державне управління в Україні; структура функціонального субрівня включає два ступені нормативно-правового регулювання: регулювання законами та підзаконними нормативно-правовими актами; у структурі нормативно-правового рівня оптимізації центральних органів виконавчої влади запропоновано виділяти концептуальний і функціональний субрівні; у зв'язку з асиметрією нормативно-правового рівня оптимізації центральних органів виконавчої влади на концептуальному субрівні необхідно змінювати структуру законодавства, тому організація і діяльність центральних органів виконавчої влади мають регулюватися положеннями, затвердженими Кабінетом Міністрів України, а не законами.

Акцентовано увагу на тому, що важливим напрямом діджиталізації нормативно-правового рівня оптимізації системи центральних органів виконавчої влади є створення та широке впровадження у правотворчу практику комп'ютерних програм, які б перевіряли проєкти нормативно-правових актів, що регламентують діяльність органів виконавчої влади, на відповідність Конституції України та іншим нормативно-правовим актам вищої юридичної сили, відсутність або наявність різного роду неузгодженостей і дублювань з іншими документами, які регулюють подібні групи правовідносин.

Ключові слова: нормативно-правовий рівень, концептуальний субрівень, функціональний субрівень, асиметрія нормативно-правового рівня, оптимізація центральних органів виконавчої влади.

\section{Summary}

Zhuravel Ya. V. Regulatory level for optimizing the system of central executive agencies in Ukraine. Article.

The author of the article has clarified that the structural and systemic components of normative and legal regulation influence not only on the status, procedure of organization and functional characteristics of executive agencies, but also on the issues of control over the implementation of their tasks, as well as over the level of legal technique for ensuring administrative activities and ease of using necessary regulatory documentation. It has been determined that the regulatory level should be characterized by the following features: the rule of law principle, the principle of stability of legislation, the principle of legislation's mobility.

It has been theoretically substantiated that: one of the priority areas of administrative reform in Ukraine is the creation of a new legal base that will regulate public administration in Ukraine; the structure of the functional sub-level includes two levels of normative and legal regulation: regulation by laws and bylaws; conceptual and functional sub-levels have been offered to be distinguished in the structure of regulatory level for optimizing central executive agencies; due to the asymmetry of the regulatory level for optimizing central executive agencies at the conceptual sub-level, it is necessary to change the structure of legislation, so the organization and activities of central executive agencies should be regulated by the provisions approved by the Cabinet of Ministers, not by laws.

The emphasis has been placed on the fact that an important direction for digitalization of regulatory level for optimizing the system of central executive agencies is the creation and widespread implementation of the software into law-making practice that would check the draft regulatory acts regulating the activities of executive agencies for their compliance with the Constitution of Ukraine and other regulatory acts of higher legal force, the absence or presence of various inconsistencies and duplications with other documents regulating similar groups of legal relations.

Key words: regulatory level, conceptual sub-level, functional sub-level, asymmetry of regulatory level, optimization of central executive agencies. 